\title{
Assessment of the Effectiveness of Different Methodologies for Oral Hygiene Training
}

\author{
Liliya Doichinova, Nadezhda Mitova, Peter Bakardjiev \\ Department of Pediatric Dentistry, Faculty of Dental \\ Medicine, Medical University - Sofia, Bulgaria
}

\begin{abstract}
Oral health is connected to the knowledge, motivation and level of oral hygiene of each individual. The strict conduct of oral-hygiene care is essential to maintaining good dental health. Aim: The study aims to implement three methods for oral hygiene training and to assess their effectiveness. The study covers 60 children aged 4-12 years. The children were divided into three groups depending on the method of training: I Method using motivational materials and audiovisual materials; II Method - education in the group; III Method - individual education. The assessment of the oral-hygiene status was accomplished by the simplified oral hygiene index-Greene \& Vermillion. The reported results were compared to a control group of children, who continued their traditional oral-hygiene practice. Results and conclusions: In both the experimental and control groups, prior to the training, oral hygiene was found inadequate. The results showed improvement in oral hygiene to be the most significant in children with individual training, followed by the group trained with motivational materials and children educated in a group. The oral hygiene status of the participants in the control group remains unsatisfactory at the end of the study.
\end{abstract}

Key words: oral hygiene, children, method of training, motivation.health

\section{Introduction}

Oral hygiene care is the most effective way to prevent tooth decay $(1,2,3)$. The oral hygiene of each individual reduces the risk of caries development $(4,5,6)$. Its strict conducting is indispensable for maintaining good oral health $(7,8)$. Cleaning one's teeth with a toothbrush and a toothpaste removes dental plaque $(6,9,10,11,12,13)$.

The level of oral hygiene status varies widely in the paediatric population $(2,7,8,10,14)$. Maintaining good oral hygiene is recommended from early childhood $(9,15,16)$. In the training of its rules, guidelines and 
monitoring are important for creating effective habits of brushing their teeth in children of all ages $(13,14$, $17,18)$.

Oral health is related to the awareness, motivation and level of oral hygiene of each individual $(4,5,6)$. It reduces dental caries risk.

\section{Matherials and Methods}

The study covered 60 children of age $4-12$ years. The children were divided in three groups based on the educational method used: I method using motivational materials, adapted for the respective age group, where the dentist illustrates proper oral hygiene techniques by using audiovisual materials, supported by showing motivational films of the French Oral and Dental Health Union, UFSBD (Union Francaise pour la Sante Bucco - Dentaire) and cartoons, videotaped by Colgate and the American Dental Association; II Method - education in the group is conducted by demonstrating the oral hygiene practice on a demonstration model for older children and on motivational puppets with jaws for the youngerler ones; III Method - individual education.

Oral hygiene status assessment was done by using the simplified oral status index of Greene \& Vermillion. The reported results were compared to a control group of children, who followed their traditional oral-hygiene practice. The correction of the existing oral hygiene habits in children was reviewed for one month as was done every week to assess oral hygiene.

For statistical analysis of the data the standard t-test was used. Statistical data processing was performed by SPSS for Windows 11.5 .

\section{Results}

At the very beginning of this study we conducted assessment of children's baseline oral hygiene status and their oral hygiene practices and skills.

Table 1. Oral hygiene in children using motivation materials for education

\begin{tabular}{|c|c|c|c|c|}
\hline $\begin{array}{l}\text { using } \\
\text { motivation } \\
\text { materials } \\
\mathrm{n}=20\end{array}$ & $\begin{array}{c}1 \\
\text { Baseline } \\
\text { OHI }\end{array}$ & $\begin{array}{c}2 \\
\text { After } \\
1 \text { week }\end{array}$ & $\begin{array}{c}3 \\
\text { After } \\
2 \text { weeks }\end{array}$ & $\begin{array}{c}4 \\
\text { After } \\
1 \text { month }\end{array}$ \\
\hline $\mathrm{X}$ & 1.79 & 1.56 & 1.25 & 0.91 \\
\hline SD & 0.29 & 0.21 & 0.22 & 0.20 \\
\hline$T, p$ & & $T 1,2=3.29 p<0.001$ & $\begin{array}{l}T 1,3=9.0 \\
p<0.001\end{array}$ & $T 1,4=10.23 \quad p<0.001$ \\
\hline
\end{tabular}

Table 1 gives the oral hygiene index results of the children, educated using the audiovisual method. The results during the entire period of oral hygiene motivation and education were compared to the control group of children. 
It became clear that the baseline oral hygiene of the children was unsatisfactory. This was easy to explain, because until this very moment they had not been educated in proper oral hygiene maintenance. A week after the first educational session we witnessed $\mathrm{OHI}$ value reduction. During this short period the children didn't master well the proper oral hygiene techniques in order to get significant improvement of their oral hygiene. Such a change was visible in the second week, which was also confirmed by higher statistical credibility. This trend continued until the end of this study with the same statistical credibility.

Table 2. Oral hygiene in children using motivational materials for education and controls

\begin{tabular}{|c|c|c|c|c|}
\hline$\overbrace{\substack{\text { Control group } \\
n=20}}^{\mathrm{OHI}}$ & $\begin{array}{c}1 \\
\text { Baseline } \\
\text { OHI }\end{array}$ & $\begin{array}{c}2 \\
\text { After } \\
1 \text { week }\end{array}$ & $\begin{array}{c}3 \\
\text { After } \\
2 \text { weeks }\end{array}$ & $\begin{array}{c}4 \\
\text { After } \\
1 \text { month }\end{array}$ \\
\hline & 1.92 & 1.81 & 1.73 & 1.60 \\
\hline SD & 0.29 & 0.21 & 0,22 & 0.20 \\
\hline,$p$ & & $\begin{array}{l}t=1.27 \\
p>0.05\end{array}$ & $\begin{array}{l}t=2.20 \\
p<0.05\end{array}$ & $\begin{array}{l}t=1.29 \\
p>0.05\end{array}$ \\
\hline $\begin{array}{l}, \mathrm{p} \\
\text { Experimental group (using motivation } \\
\text { materials) and } \\
\text { controls }\end{array}$ & $\begin{array}{c}T=0.1,51 \\
p>0.05\end{array}$ & $\begin{array}{c}\mathrm{T} 1,2=3.57 \\
\mathrm{p}>0.001\end{array}$ & $\begin{array}{l}T 1,3=8.0 \\
p>0.001\end{array}$ & $\begin{array}{c}T 1,4=10.62 \\
p>0.001\end{array}$ \\
\hline
\end{tabular}

The baseline oral hygiene for the control group was also unsatisfactory. Among those children some reduction of $\mathrm{OHI}$ values was observed in the first two weeks, without any statistically significant difference to the baseline level. Such significant difference was reported on their visit. After that, at the end of the study again there was worsening of the oral hygiene among these children. The oral hygiene during the monitored experimental period was not good, which indicated the necessity of motivation and education in this group

Table 3. Oral hygiene in children educated in the group

\begin{tabular}{|c|c|c|c|c|}
\hline $\begin{array}{l}\text { Education } \\
\text { in the group } \\
n=20\end{array}$ & $\begin{array}{c}1 \\
\text { Baseline } \\
\text { OHI }\end{array}$ & $\begin{array}{c}2 \\
\text { After } \\
1 \text { week }\end{array}$ & $\begin{array}{c}3 \\
\text { After } \\
2 \text { weeks }\end{array}$ & $\begin{array}{c}4 \\
\text { After } \\
1 \text { month }\end{array}$ \\
\hline & 1.81 & 1.61 & 1.32 & 1.08 \\
\hline SD & 0.29 & 0.23 & 0.17 & 0.20 \\
\hline,$p$ & & $\begin{array}{l}t=2.32 \\
p<0.05\end{array}$ & $\begin{array}{c}t=6.12 \\
p<0.001\end{array}$ & $\begin{array}{c}t=9.2 \\
p<0.001\end{array}$ \\
\hline
\end{tabular}

Output data for the oral hygiene index of children from the second experimental group shows that here the values are also within the limits of the unsatisfactory oral hygiene. From the second visit to the end of the training program the trend is retained for improvement of their oral hygiene. 
Table 4. Oral hygiene in children educated in the group and controls

\begin{tabular}{|c|c|c|c|c|}
\hline$\underbrace{\mathrm{OHI}}_{\substack{\mathrm{C}=20 \\
\text { Control group }}}$ & $\begin{array}{c}1 \\
\text { Baseline } \\
\text { OHI }\end{array}$ & $\begin{array}{c}2 \\
\text { After } \\
1 \text { week }\end{array}$ & $\begin{array}{c}3 \\
\text { After } \\
2 \text { weeks }\end{array}$ & $\begin{array}{c}4 \\
\text { After } \\
1 \text { month }\end{array}$ \\
\hline & 1.92 & 1.81 & 1.73 & 1.60 \\
\hline SD & 0.29 & 0.21 & 0.22 & 0.20 \\
\hline,$p$ & & $\begin{array}{c}\mathrm{T} 1,2=1.27 \\
\mathrm{p}>0.05\end{array}$ & $\begin{array}{c}\mathrm{T} 1,3=2.20 \\
\mathrm{p}<0.05\end{array}$ & $\begin{array}{c}\mathrm{T} 1,4=1.29 \\
\mathrm{p}>0.05\end{array}$ \\
\hline $\begin{array}{l}, \mathrm{p} \\
\text { Experimental group (education in the } \\
\text { group) and controls }\end{array}$ & $\begin{array}{r}=1.22 \\
p>0.05\end{array}$ & $\begin{array}{c}T 1,2=2.85 \\
p<0.01\end{array}$ & $\begin{array}{c}T 1,3=6.83 \\
p<0.001\end{array}$ & $\begin{array}{c}\mathrm{T} 1,4=12.14 \\
\mathrm{p}<0.001\end{array}$ \\
\hline
\end{tabular}

The comparison of results of the control group and those of the children educated in the groups shows that from the first week onwards a statistically significant difference was observed until the end of the study period.

Table 5. Oral hygiene in children with individual education

\begin{tabular}{|c|c|c|c|c|}
\hline individual $\underbrace{O H I}_{n=20}$ education & $\begin{array}{c}1 \\
\text { Baseline } \\
\text { OHI }\end{array}$ & $\begin{array}{c}2 \\
\text { After } \\
1 \text { week }\end{array}$ & $\begin{array}{c}3 \\
\text { After } \\
2 \text { weeks }\end{array}$ & $\begin{array}{c}4 \\
\text { After } \\
1 \text { month }\end{array}$ \\
\hline & 1.83 & 1.56 & 1.26 & 0.76 \\
\hline SD & 0.28 & 0.30 & 0.24 & 0.23 \\
\hline,$p$ & & $\begin{array}{r}T 1,2=3 . \\
p<0.01\end{array}$ & $\mathrm{~T} 1,3=7.30 \mathrm{p}<0.001$ & $\begin{array}{c}T 1,4=13.7 \\
p<0.001\end{array}$ \\
\hline
\end{tabular}

The data in Table 5 show that the level of oral hygiene for children in the third group is also within the unsatisfactory range. But in the course of ongoing individual instruction from the second visit an improvement in the oral hygiene of the children is noticeable, and in subsequent visits this trend continues with the most significant change the end of the training program for the study, supported with high statistical confidence. 
Table 6. Oral hygiene in the group with individual education and controls

\begin{tabular}{|c|c|c|c|c|}
\hline Control group & $\begin{array}{c}1 \\
\text { Baseline } \\
\text { OHI }\end{array}$ & $\begin{array}{c}2 \\
\text { After } \\
1 \text { week }\end{array}$ & $\begin{array}{c}3 \\
\text { After } \\
2 \text { weeks }\end{array}$ & $\begin{array}{c}4 \\
\text { After } \\
1 \text { month }\end{array}$ \\
\hline & 1.92 & 1.81 & 1.73 & 1.60 \\
\hline SD & 0.29 & 0.21 & 0.22 & 0.20 \\
\hline,$p$ & & $\begin{array}{c}\mathrm{T} 1,2=1.27 \\
\mathrm{p}>0.05\end{array}$ & $\begin{array}{c}\mathrm{T} 1,3=2.20 \\
\mathrm{p}<0.05\end{array}$ & $\begin{array}{c}\mathrm{T} 1,4=1.29 \\
\mathrm{p}>0.05\end{array}$ \\
\hline $\begin{array}{l}\text {, } \mathrm{p} \\
\text { Experimental group (with individual } \\
\text { education) and } \\
\text { controls }\end{array}$ & $\begin{array}{l}T=1.0 \\
p>0.05\end{array}$ & $\mathrm{~T} 1,2=2.90 \mathrm{p}<0.001$ & $\begin{array}{c}T 1,3=6.71 \\
p<0.001\end{array}$ & $\begin{array}{c}T 1,4=16.6 \\
p<0.001\end{array}$ \\
\hline
\end{tabular}

When comparing the results of the third experimental group and the control group of children the high statistical reliability for the entire period of the study is seen.

\section{Discussion}

Oral hygiene care is the most effective prevention. Strict adherence to oral hygiene care is mandatory for good dental health maintenance.

In pediatric population the level of oral hygiene status varies within a wide range $(2,7,10,14)$. Maintaining good oral hygiene is recommendable from early childhood. In teaching its procedures both instructions and supervision are important for establishing effective tooth brushing habits among children of all ages. They should brush their teeth twice daily, preferably after breakfast in the morning and before going to bed in the evening. Tooth brushing with a toothbrush and a tooth paste removes dental plaque, keeps the mouth clean and healthy and improves both the child's breath and maintains a fresh feeling of taste.

The results obtained in the experimental groups and their controls for the duration of the study revealed significant differences. Oral hygiene improvement in the three groups of children was clearly outlined. Most effective oral hygiene influence was observed in the group subject to individual education and instruction. We had good results in the group of children where the audiovisual method was applied. The results in the group educated by using a model were the most modest. Oral hygiene improvement in the last two experimental groups reveals that these methods must be used in combination with individual training, instructions and motivation of the children. Using appropriate motivational materials has a significant impact on the oral hygiene status of the children. Motivation is one of the most important factors in the process of dental plaque control.

The oral hygiene in the control group of children demonstrates higher values of oral hygiene index for the whole period of observation.

Stutcliffe et al (19) concluded that programs for oral hygiene instructions have potential value as a means of introducing young children to future dental procedures in the most pleasant way possible. These data 
confirmed earlier studies $(20,21)$, which show that instruction and supervision are important for the creation of effective brushing habits in children. Ogasawara et al. (22) claim that it is possible to provide effective guidance in brushing to preschool children, while the instructions are adapted to their age. Unkel et al. (23) showed that chronological age is a reasonable predictor of brushing ability and hand-brushing skills are acquired after about four to five years. WHO defined dental plaque as a specific but highly variable structural unit, as a result of the successive colonization of microorganisms on the surfaces of teeth, restorations and other parts of the oral cavity consisting of salivary components such as mucin, desquamated epithelial cells, debris, and microorganisms, all in the extracellular gelatinous matrix (24). It is assumed that the mechanical and chemical control measures of plaque are useful for prevention of caries and gingivitis by reducing the plaque (20). Tooth brushing and other mechanical measures are the most practical and effective means of achieving and maintaining adequate oral hygiene $(25,26,27)$. It has been reported that the horizontal technique for cleaning the teeth is the method of choice by young children (28). Motivation is one of the most important factors in providing optimal control of plaque.

Although brushing is a simple and effective way to remove dental plaque, the prevalence of periodontal disease in the general population shows that it is insufficient $(16,23,25,29,30,31,32,33,34)$.

Oral health education and training were effective in establishing good oral health habits among school children and also in enhancing the knowledge of their parents about good oral health $(36,37)$.

The school-based caries preventive program comprised oral hygiene instructions and supervised toothbrushing education was effective in imparting oral health knowledge and establishing good oral hygiene habits in school children and in improving their oral hygiene status and the attitudes of their parents $(37,38)$.

Assessment of the effectiveness of teaching methods of oral hygiene is being studied by different authors $(39,40,41)$.

Vivek Rana et al. assess the effectiveness of 3 methods of teaching tooth brushing in young children with mixed dentition: audio-visual aids, individual instructions to each child on cast and child as model along with the effect of reinforcement on the learning skills of the child (39). Their results, which are similar to ours, showed that the most effective method of oral hygiene instruction and reinforcement was individual instruction independent of the age of the child. This information is useful because this method is both inexpensive and easily taught.

Almut Makuch et al. compare artificial tooth-brushing models (TBM) and individual modeling regarding their efficacy in teaching the correct brushing movements to younger preschool children (40). It was shown that human models achieved greatest learning success. But their combination with individual learning methods in oral hygiene has better outcomes, as demonstrated in our study. It is important to find a "helper" and an attractive model person assisting in guiding the brush with feedback in a mirror.

Children should be educated in oral self-care according to their status of psychological development (41). In the scientific literature the need for tooth-brushing instructions in young children according to their manual skills is affirmed (42). The required manual dexterity for tooth brushing was present in younger age groups. Instructions should be given according to the child's degree of readiness for tooth brushing 
and their status of psychological development and should include systematic training and reinforcement. Intensive individual training is essential.

\section{Conclusion}

The three methods of oral hygiene education can be used effectively with children of different age groups. All the three methods of education improved oral hygiene. Good motivation by using skillfully selected motivational materials is crucial for education. The results reveal that the most effective method of oral hygiene education and practicing proper tooth brushing technique is individual instruction, irrespective of the age group. Instruction and education in oral hygiene procedures, as well as control of the level of dental plaque, are important factors for its effective removal.

\section{References}

1. Blinkhorn A., Gratrix D, Holloway P. et al. A cluster randomised, controlled trial of the value of dental health educators in general dental practice. Br Dent J 2003; 11: 395-400

2. O'Leary T., Drake R., Naylor J. The plaque control record. J Periodontology 1972; 43: 38-39

3. Valle D., de Carvalho Vianna R. Evaluation of an oral health promotion program using different indicators. J Clin Pediatr Dent 2004; 29: 87-92.

4. Freitas-Fernandes L., Novaes Junior A. et al. Effectiveness of an oral hygiene program for Brazilian orphans. Braz Dent J 2002; 13: 144-148.

5. Green J.C, Vermillion J. The oral hygiene index: a method for classifying oral hygiene status. JADA 1960; 61: 172-179.

6. Mascarenhas A.K., Soparkar P., Al-Mutawa S. et al. Plaque removal using a battery-powered toothbrush compared to a manual toothbrush. J Clin Dent 2005; 16: 123-125.

7. Ogasawara, T., Watanabe, T. Readiness for toothbrushing of young children. J Dent for Child 1992; 59: 353-359.

8. Prevention methods and programmes for oral diseases. Report of a WHO Expert Committee Geneva 1984.

9. Nourallah A., Splieth C. Efficacy of occlusal plaque removal in erupting molars: a comparison of an electric toothbrush and the cross-toothbrushing technique. Caries Res 2004: 38: 291-294.

10. Prevention of Oral Deseases. WHO offset Publication № 103, WHO Geneva 1987.

11. Thomas S, Tandon S, Nair S. Effect of dental health education on the oral health status of a rural child population by involving target groups. J Indian Soc Pedod Prev Dent 2000; 18: 115-125.

12. Van Palenstein Helderman WH, Kyaing M,. Aung MT, et al. Plaque removal by young children using old and new toothbrushes. J Dent Res 2006; 12: 1138-1142. 
13. Vanobbergen J, Declerck D, Mwalili S, et al. The effectiveness of a 6-year oral health education programme for primary schoolchildren. Community Dent Oral Epidemiol 2004; 32: 173-182.

14. Tsamtsouris A., White G., Clark E. The effect of instruction and supervised toothbrushing on the reduction of dental plaque in kindergarten children. J Dent for Child 1979; 46: 204-209.

15. Garcia-Godoy F, Marcushamer M, Cugini M,. et al. The safety and efficacy of a children's power toothbrush and a manual toothbrush in 6-11 year-olds. Am J Dent 2001; 14: 195-199.

16. McClure D. A comparison of toothbrushing techniques for the preschool child. J Dent for Child 1966; 33: 205-210.

17. Rugg-Gunn A., Macgregor I. A survey of toothbrushing behaviour in children and young adults. J Periodont Res 1978; 13: 382-389.

18. Zimmer S, Didner B, Roulet J. Clinical study on the plaque-removing ability of a new tripleheaded toothbrush. J Clin Periodontol 1999; 26: 281-285.

19. Stutcliffe P, Wishart WA, Naomi C. Supervised toothbrushing in a nursery school. Brit Dent J 1977; 147: 192-194.

20. Okada M, Kuwahara S, Kaihara $\mathrm{Y}$, Ishidori H, Kawamura M, Miura K, Negasaka Net al. Relationship between gingival health and dental caries in children aged 7-12 years. J Oral Sci 2000;42: 151-155.

21. Tsamtsouris A, White GE, Clark ER. The effect of instruction and supervised toothbrushing on the reduction of dental plaque in kindergarten children. J Dent Children 1979; 36: 204-209.

22. Ogasawara $\mathrm{T}$, Watanabe $\mathrm{T}$, Kasahara $\mathrm{H}$. Readiness for toothbrushing of young children. J Dent Children 1992; 5: 353-359.

23. Unkel JH, Fenton SJ, Hobbs G, Frere CLet al. Toothbrushing ability is related to age in children. J Dent Children 1995; 5:3 46-348.

24. World Health Organization (1961) Periodontal disease. Tech report series No207. Geneva, USA.

25. Beal JF, James PM, Bradnock G, Anderson RJet al. The relationship between dental cleanliness, dental caries incidence and gingival health. A longitudinal study. Br Dent J 1979; 146: 111-114.

26. Town Gl. The role of oral hygiene in the prevention of periodontal disease and dental caries. N Z Dent J 1979; 75: 29-33.

27. Axelsson P, Lindhe J. Effect of controlled oral hygiene procedures on caries and periodontal disease in adults. J Clin Periodontol 1978; 5: 133-151.

28. Sten OS, Hortense K. (1983) Tooth brushing behaviour in children: a study of pressure and stroke frequency. Pediat Dent 1983;4: 225-227.

29. Coonts EJ. Periodontics and oral hygiene. Quint Int 1983; 7: 739-742. 
30. Kühner $M$, Raetzke P. Relative effectiveness of various alternating frequencies of a power toothbrush. J Clin Periodontol 1993; 20: 75-80.

31. Almajed I. A comparative study between the double-headed toothbrush and the single headed toothbrush in plaque removal efficiency. J Clin Pediatr Dent 1994; 19: 19-21.

32. McCracken GI, Heasman L, Stacey F, Kelly PJ, Heasman PAet al. Testing the efficacy of plaque removal of a prototype brush head for a powered toothbrush. J Clin Periodontol 2000; 27: 542-548.

33. Macgregor ID, Rugg-Gunn AJ. Toothbrushing duration in 60 uninstructed young adults. Community Dent Oral Epidemiol 1985;13:121-2. Macgregor ID, Rugg-Gunn AJ. Toothbrushing duration in 60 uninstructed young adults. Community Dent Oral Epidemiol 1985; 13: 121-2.

34. Macgregor ID, Rugg-Gunn AJ. Survey of toothbrushing duration in 85 uninstructed English school children. Community Dent Oral Epidemiol 1979;7:297-298.

35. Mentes A, Atukeren J. A Study of Manual Toothbrushing Skills in Children Aged 3-11 years. J Clin Pediatr Dent 2002; 27: 91-94.

36. Martins CC, Oliveira MJ, Pordeus IA, Paiva SMet al. Comparison between observed children's tooth brushing habits and those reported by mothers. BMC Oral Health 2011; 11: 22.

37. Turska-Szybka A, Gozdowski D, Olczak-Kowalczyk D. Impact of individual health-oriented parent education on eating and hygienic habits, oral hygiene level, and dentition condition in children with high risk of caries. Dev Period Med 2014; 18: (22):: 233-40.

38. Pullishery F, Shenoy Panchmal G, Shenoy R. Parental Attitudes and Tooth Brushing Habits in Preschool Children in Mangalore, Karnataka: A Cross-sectional Study. Int J Clin Pediatr Dent 2013; 6:(3): 156-160.

39. Srivastava N, Vasishat A, Gupta G, Rana Vet al. A Comparative Evaluation of Efficacy of Different Teaching Methods of Tooth Brushing in Children Contributors. Oral Hyg Health V 2013; 1: 118.

40. Almut Makuch A, Konrad Reschke K, Stefan Rupf St. Effective teaching of tooth-brushing to preschool children. J Dent Child (Chic) 2011; 78: (1): 9-12.

41. Zimmer S, Bizhang M, Seemann R, Barthel CRet al. Effectiveness of preventive programs on oral hygiene of adults and school children. Gesundheitswesen 2001; 63: 98-101.

42. Das $U$ M, Singhal P. Tooth brushing skills for the children aged 3-11 years. J Indian Soc Pedod Prev Dent 2009; 27: 104-107.

\section{Corresponding author:}

Liliya Doichinova

Department of Pediatric Dental Medicine

Faculty of Dental Medicine - Sofia

e-mail: Idoitchinova@abv.bg 